\title{
Antioxidant-enzymatic system of two sorghum genotypes differing in salt tolerance
}

\author{
Paulo Henrique Alves da Costa ${ }^{1}$, André Dias de Azevedo Neto ${ }^{2}$, Marlos Alves Bezerra ${ }^{3}$, José Tarquinio Prisco ${ }^{1}$ \\ and Enéas Gomes-Filho ${ }^{1 *}$
}

\begin{abstract}
${ }^{1}$ Departamento de Bioquímica e Biologia Molecular, Universidade Federal do Ceará, Caixa Postal 6039, 60455-900, Fortaleza, CE, Brazil; ${ }_{2}^{2}$ Departamento de Biologia, Universidade Federal Rural de Pernambuco, 52171-900, Recife, PE, Brazil; ${ }^{3}$ Embrapa Agroindústria TropicalCNPAT, Fortaleza, CE, Brazil; *Corresponding author: egomesf@ufc.br
\end{abstract}

Received: 05/10/2005, Accepted: 10/12/2005

Two forage sorghum genotypes were studied: CSF18 (salt-sensitive) and CSF20 (salt-tolerant). Shoot growth reduction as a result of salt stress was stronger in the salt sensitive genotype compared to the salt tolerant one. When the two genotypes were subjected to salt stress $(75 \mathrm{mM} \mathrm{NaCl})$ no significant change in lipid peroxidation was observed. However, salt stress induced increases in superoxide dismutase and catalase activities in both genotypes. These salt-induced increases were higher in the salt-tolerant genotype. Peroxidase activity was differentially affected by salt stress in the two genotypes. The activities of these peroxidases were decreased by salt stress in the salt-sensitive genotype and increased in the salt-tolerant genotype. In addition, the activity ratio between the superoxide dismutase and the $\mathrm{H}_{2} \mathrm{O}_{2}$-scavenging enzymes was higher in the salt-sensitive genotype. The results obtained support the hypothesis that the higher efficiency of the antioxidant-enzymatic system of the CSF20 genotype could be considered as one of the factors responsible for its tolerance to salt stress. Therefore, it is suggested that the ratio between superoxide dismutase and $\mathrm{H}_{2} \mathrm{O}_{2}$-scavenging enzyme activities could be used as a working hypothesis for a biochemical marker for salt tolerance in sorghum.

Key words: Sorghum bicolor, antioxidant-enzymatic system, lipid peroxidation, oxidative stress, salinity.

Sistema enzimático antioxidante de dois genótipos de sorgo diferindo na tolerância à salinidade: Dois genótipos de sorgo forrageiro foram estudados: CSF18 (sensível) e CSF20 (tolerante). A redução no crescimento da parte aérea devida ao estresse salino foi maior no genótipo sensível. Quando ambos foram submetidos ao estresse salino ( $\mathrm{NaCl}$ a $75 \mathrm{mM})$, não se observou nenhuma mudança significativa na peroxidação dos lipídios. Contudo, o estresse salino induziu aumentos nas atividades da dismutase do superóxido e da catalase de ambos os genótipos. Tais aumentos foram maiores no genótipo tolerante. As atividades das peroxidases foram diferencialmente afetadas pelo estresse salino. Enquanto no genótipo sensível houve descréscimos, no genótipo tolerante observaram-se aumentos nas atividades dessas enzimas em resposta a salinidade. Além disso, a razão de atividade entre a dismutase do superóxido e as demais enzimas foi maior no genótipo sensível. Os resultados sustentam a hipótese de que a maior eficiência do sistema enzimático antioxidante do genótipo CSF20 poderia ser considerada como um dos fatores responsáveis por sua tolerância ao estresse salino. Portanto, a razão entre as atividades da dismutase do superóxido e a das enzimas eliminadoras do $\mathrm{H}_{2} \mathrm{O}_{2}$ poderia ser usada como hipótese de trabalho de um marcador bioquímico de tolerância ao estresse salino em sorgo.

Palavras-chave: Sorghum bicolor, estresse oxidativo, peroxidação de lipídios, sistema enzimático antioxidante, tolerância ao sal.

\section{INTRODUCTION}

Salinity tolerance has been studied in relation to regulatory mechanisms of osmotic and ionic homeostasis (Ashraf and Harris, 2004). Salt stress, like other abiotic stresses, can also lead to oxidative stress through the increase in reactive oxygen species (ROS), such as superoxide $\left(\mathrm{O}_{2}{ }^{--}\right)$, hydrogen peroxide $\left(\mathrm{H}_{2} \mathrm{O}_{2}\right)$ and hydroxyl radicals $\left(\mathrm{OH}^{\circ}\right)$, which are highly reactive and may cause cellular damage through oxidation of lipids, proteins and nucleic acids (McKersie and Leshem, 1994; Pastori and Foyer, 2002; Apel 
and Hirt, 2004). To minimize the effects of oxidative stress, plant cells have evolved a complex antioxidant system, which is composed of low-molecular mass antioxidants (glutathione, ascorbate and carotenoids) as well as ROS-scavenging enzymes, such as: superoxide dismutase (SOD), calatase (CAT), ascorbate peroxidase (APX), guaiacol peroxidase (GPX), and glutathione reductase (GR) (Alscher et al., 1997; Apel and Hirt, 2004). ROS-scavenging enzymes are present in different cellular compartments as isoenzymes (Asada, 1992; Alscher et al., 2002; Shigeoka et al., 2002; Apel and Hirt, 2004). The generation of ROS and increased activity of many antioxidant enzymes during salt stress have been reported in cotton (Gosset et al., 1994), mulberry (Sudhakar et al., 2001), wheat (Sairam et al., 2002), tomato (Mittova et al., 2002), rice (Vaidyanathan et al., 2003), sugar beet (Bor et al., 2003), and maize (Azevedo Neto et al., 2005a). Most of the data from these studies suggest a correlation between stress tolerance and the presence of an efficient antioxidant system. However, this salt-tolerance mechanism is still not fully understood. Although there are several papers dealing with salt tolerance in sorghum (Bernstein et al., 1995; Lacerda et al., 2001; 2003 and 2005), no reference dealing with oxidative damage induced by salinity in this species was found. A comparison of the antioxidant responses of forage sorghum genotypes exhibiting differential tolerance to salt stress could contribute to the understanding of the physiological and biochemical mechanisms of protection against salt-induced oxidative damage. Therefore, the present study was conducted to investigate the role of the antioxidant-enzymatic system in relation to salt tolerance in forage sorghum genotypes.

\section{MATERIAL AND METHODS}

Plant material and salinity treatments: Seeds of two forage sorghum genotypes [Sorghum bicolor (L.) Moench], CSF20 (salt-tolerant) and CSF18 (salt-sensitive) as determinated by Lacerda et al. (2001), were sown in trays containing vermiculite and irrigated daily with distilled water. Eightday-old seedlings were transferred to trays containing nutrient solution (Clark, 1975) and eleven days later transferred to 3 L plastic pots containing nutrient solution, without (control treatment) or with $75 \mathrm{mM} \mathrm{NaCl}$ (saline treatment). Salt additions ( $25 \mathrm{mM} \mathrm{NaCl}$ per day) began upon transplantation into the plastic pots.

Growth measurements: Plants were harvested seventeen days after the start of $\mathrm{NaCl}$ additions, and shoot and roots were separated. Leaf area was determined using a Li-Cor area meter LI-3000 (Li-Cor., Inc., Lincoln, Nebraska, USA). The first fully expanded leaf starting from shoot apex and roots were frozen in liquid nitrogen, lyophilized, weighed, ground to a powder, and kept in a freezer $\left(-20^{\circ} \mathrm{C}\right)$ for further analyses. The rest of the plant material was weighed after drying in a forced air circulation oven at $65^{\circ} \mathrm{C}$ for $72 \mathrm{~h}$. The experiment was carried out under greenhouse conditions. The mean values of temperature, air relative humidity and the photosynthetic active radiation at midday were $27 \pm 4.2^{\circ} \mathrm{C}$, $65 \pm 12.2 \%$ and $1200 \pm 326 \mu \mathrm{mol} \cdot \mathrm{m}^{-2} \cdot \mathrm{s}^{-1}$, respectively.

Preparation of extracts: Lyophilized leaf $(0.20 \mathrm{~g})$ and root $(0.15 \mathrm{~g})$ powders were homogenized in a mortar and pestle with $4 \mathrm{~mL}$ of ice-cold extraction buffer $(100 \mathrm{mM}$ potassium phosphate buffer, $\mathrm{pH}$ 7.0, 0.1 mM EDTA). Although the inclusion of ascorbate in the APX extraction media is recommended (Asada, 1992), preliminary experiments have shown that its absence did not alter APX activity. For this reason, ascorbate was omitted from the extracting buffer. The homogenate was filtered through muslin cloth and centrifuged at $16,000 g_{\mathrm{n}}$ for $15 \mathrm{~min}$. The supernatant fraction was used as a crude extract for lipid peroxidation and enzyme activity assays. All operations were carried out at $4{ }^{\circ} \mathrm{C}$, and one extract was made per plant part.

Lipid peroxidation: Lipid peroxidation was determined by measuring the amount of malondialdehyde (MDA) produced by the thiobarbituric acid reaction as described by Heath and Packer (1968). The crude extract was mixed with the same volume of a $0.5 \%(\mathrm{w} / \mathrm{v})$ thiobarbituric acid solution containing $20 \%(\mathrm{w} / \mathrm{v})$ tricholoroacetic acid. The mixture was heated at $95^{\circ} \mathrm{C}$ for $30 \mathrm{~min}$ and then quickly cooled in an icebath. The mixture was centrifuged at 3,000 $g_{\mathrm{n}}$ for $5 \mathrm{~min}$ and the absorbance of the supernatant measured at 532 and 600 $\mathrm{nm}$. The MDA concentration was determined by dividing the difference in absorbance $\left(A_{532}-A_{600}\right)$ by its molar extinction coefficient $\left(155 \mathrm{mM}^{-1} \cdot \mathrm{cm}^{-1}\right)$, and the results expressed as $\mu$ mol. $\mathrm{g}^{-1}$ dry mass (DM).

Enzyme assays: Specific SOD (EC 1.15.1.1) activity was determined by measuring its ability to inhibit the photochemical reduction of nitroblue tetrazolium chloride, as described by Giannopolitis and Ries (1977). The assay mixture consisted of $50 \mu \mathrm{L}$ of the enzyme extract, $50 \mathrm{mM}$ phosphate buffer (pH 7.8), 0.1 $\mu \mathrm{M}$ EDTA, $13 \mathrm{mM}$ methionine, $75 \mu \mathrm{M}$ nitroblue tetrazolium and $2 \mu \mathrm{M}$ riboflavin in a total volume of $1.5 \mathrm{~mL}$. Riboflavin was added last and tubes were 
shaken and placed under fluorescent lighting from two $20 \mathrm{~W}$ tubes. The reaction was allowed to proceed for $15 \mathrm{~min}$, after which the lights were switched off and the tubes covered with a black cloth. Absorbance of the reaction mixture was read at $560 \mathrm{~nm}$, and one unit of SOD activity (U) was defined as the amount of enzyme required to cause $50 \%$ inhibition of the nitroblue tetrazolium photoreduction rate. The results were expressed as U.mg ${ }^{-1}$ protein.

Specific CAT (EC 1.11.1.6) activity was measured according to Beers and Sizer (1952), with minor modifications. The assay mixture consisted of $50 \mu \mathrm{L}$ of the enzyme extract, $100 \mathrm{mM}$ phosphate buffer ( $\mathrm{pH}$ 7.0), $0.1 \mu \mathrm{M}$ EDTA, and 20 $\mathrm{mM} \mathrm{H}_{2} \mathrm{O}_{2}$ in a total volume of $1.5 \mathrm{~mL}$. The decrease of $\mathrm{H}_{2} \mathrm{O}_{2}$ was monitored by reading the absorbance at $240 \mathrm{~nm}$ at the moment of $\mathrm{H}_{2} \mathrm{O}_{2}$ addition and 1 min later. The difference in absorbance $\left(\Delta A_{240}\right)$ was divided by the $\mathrm{H}_{2} \mathrm{O}_{2}$ molar extinction coefficient $\left(36 \mathrm{M}^{-1} \cdot \mathrm{cm}^{-1}\right)$ and the enzyme activity expressed as $\mu \mathrm{mol}$ of $\mathrm{H}_{2} \mathrm{O}_{2} \mathrm{~min}^{-1}$. $\mathrm{mg}^{-1}$ protein.

Specific APX (EC 1.11.1.1) activity was assayed according to Nakano and Asada (1981). The assay mixture consisted of $50 \mu \mathrm{L}$ of the enzyme extract, $50 \mathrm{mM}$ phosphate buffer $(\mathrm{pH}$ 6.0), $0.1 \mu \mathrm{M}$ EDTA, $0.5 \mathrm{mM}$ ascorbate, and $1.0 \mathrm{mM} \mathrm{H}_{2} \mathrm{O}_{2}$ in a total volume of $1.5 \mathrm{~mL}$. Ascorbate oxidation was monitored by reading the absorbance at $290 \mathrm{~nm}$ at the moment of $\mathrm{H}_{2} \mathrm{O}_{2}$ addition and $1 \mathrm{~min}$ later. The difference in absorbance $\left(\Delta A_{290}\right)$ was divided by the ascorbate molar extinction coefficient $\left(2.8 \mathrm{mM}^{-1} \cdot \mathrm{cm}^{-1}\right)$ and the enzyme activity expressed as $\mu \mathrm{mol}$ of $\mathrm{H}_{2} \mathrm{O}_{2} \mathrm{~min}^{-1}$. $\mathrm{mg}^{-1}$ protein, taking into consideration that $1.0 \mathrm{~mol}$ of ascorbate is required for the reduction of 1.0 mol of $\mathrm{H}_{2} \mathrm{O}_{2}$ (McKersie e Leshem, 1994).

Specific GPX (EC 1.11.1.7) activity was determined as described by Urbanek et al. (1991). The assay mixture consisted of $50 \mu \mathrm{L}$ of the enzyme extract, $100 \mathrm{mM}$ phosphate buffer (pH 7.0), 0.1 $\mu \mathrm{M}$ EDTA, $5.0 \mathrm{mM}$ guaiacol, and 15.0 $\mathrm{mM} \mathrm{H}_{2} \mathrm{O}_{2}$ in a total volume of $2.0 \mathrm{~mL}$. Guaiacol oxidation (tetraguaiacol formation) was monitored by reading the absorbance at $470 \mathrm{~nm}$ at the moment of $\mathrm{H}_{2} \mathrm{O}_{2}$ addition and 1 min later. The difference in absorbance $\left(\Delta A_{470}\right)$ was divided by the tetraguaiacol molar extinction coefficient (26.6 $\mathrm{mM}^{-1} \cdot \mathrm{cm}^{-1}$ ) and the enzyme activity expressed as $\mu \mathrm{mol}$ of $\mathrm{H}_{2} \mathrm{O}_{2} \mathrm{~min}^{-1} \cdot \mathrm{mg}^{-1}$ of protein, taking into consideration that $4.0 \mathrm{~mol}$ of $\mathrm{H}_{2} \mathrm{O}_{2}$ are reduced to produce $1.0 \mathrm{~mol}$ of tetraguaiacol (Plewa et al. 1991).

Specific GR (EC 1.6.4.2) activity was assayed as described by Foyer and Halliwell (1976), with minor modifications. The assay mixture consisted of $50 \mu \mathrm{L}$ of the enzyme extract, $100 \mathrm{mM}$ phosphate buffer (pH 7.8), $0.1 \mu \mathrm{M}$ EDTA,
$0.05 \mathrm{mM} \mathrm{NADPH}$, and $3.0 \mathrm{mM}$ oxidized glutathione in a total volume of $1.0 \mathrm{~mL}$. NADPH oxidation rate was monitored by reading the absorbance at $340 \mathrm{~nm}$ at the moment of $\mathrm{H}_{2} \mathrm{O}_{2}$ addition and $1 \mathrm{~min}$ later. The difference in absorbance $\left(\Delta A_{340}\right)$ was divided by the NADPH molar extinction coefficient $\left(6.22 \mathrm{mM}^{-1} . \mathrm{cm}^{-1}\right)$ and the enzyme activity expressed as $\mu \mathrm{mol}$ of NADPH $\mathrm{min}^{-1} \cdot \mathrm{mg}^{-1}$ protein.

In all the enzyme assays protein was determined by the method of Bradford (1976) using bovine serum albumin (Sigma-Aldrich Co., USA) as standard.

Experimental design: The experimental design was a completely randomized 2 (genotypes) $\times 2$ (salt levels) factorial, with five replicates of one plant each. For each one of the enzyme assays five replicate extracts were used of each plant part, and the assays carried out in duplicate. The data were expressed as the means \pm standard deviation.

\section{RESULTS}

Figure 1 shows that salt stress induced a reduction in both shoot dry mass and leaf area of both salt-sensitive and salt-tolerant genotypes. Leaf area was reduced by 38.4 and $27.8 \%$, while the reductions in shoot dry mass were 31.2 and $18.1 \%$, in salt-sensitive and salt-tolerant genotypes, respectively. Root dry matter was not affected by salt stress in both salt-sensitive and salt-tolerant genotypes (data not shown).

Lipid peroxidation, assessed through malondialdehyde (MDA) content (figure 2), was higher in leaves than in roots independent of the treatment and genotype. However, it was not affected by salt stress, either in leaves or roots from plants of both genotypes. Superoxide dismutase (SOD) activity, on the other hand, increased in both salt-sensitive and salt-tolerant genotypes in response to salt stress (figure 2). Leaf-SOD activity from stressed plants was 49.5 and $38.2 \%$ higher than in the controls for the salt-sensitive and salt-tolerant genotypes, respectively. Root-SOD activity values from plants of the saline treatment were higher than those of leaf-SOD from stressed plants of both genotypes. Consequently, the increases in rootSOD activities due to salt-stress were $128.5 \%$ and $218.8 \%$ in salt-sensitive and salt-tolerant genotypes, respectively.

Salt stress did not affect leaf-CAT activity (figure 3 ) in plants of the salt-sensitive genotype, but induced a 682.8 $\%$ increase in activity of this enzyme in plants of the salttolerant genotype. Root-CAT activity increased in both genotypes as a result of salt stress. The increase in the saltsensitive genotype was $302.9 \%$ and that of the salt-tolerant genotype $773.5 \%$. 

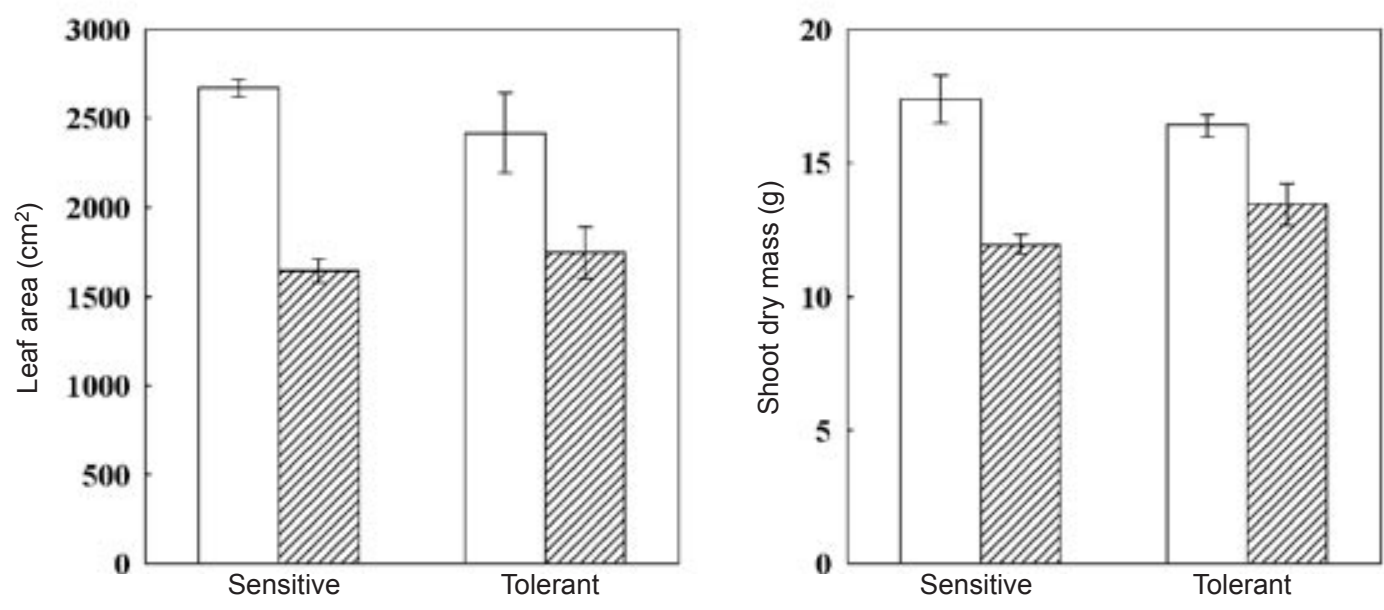

Figure 1. Leaf area and shoot dry mass of two sorghum genotypes, differing in salt-tolerance. Plants were grown under control $(\square)$ and saline $(\square)$ conditions; values represent the mean and the bars indicate standard deviation.

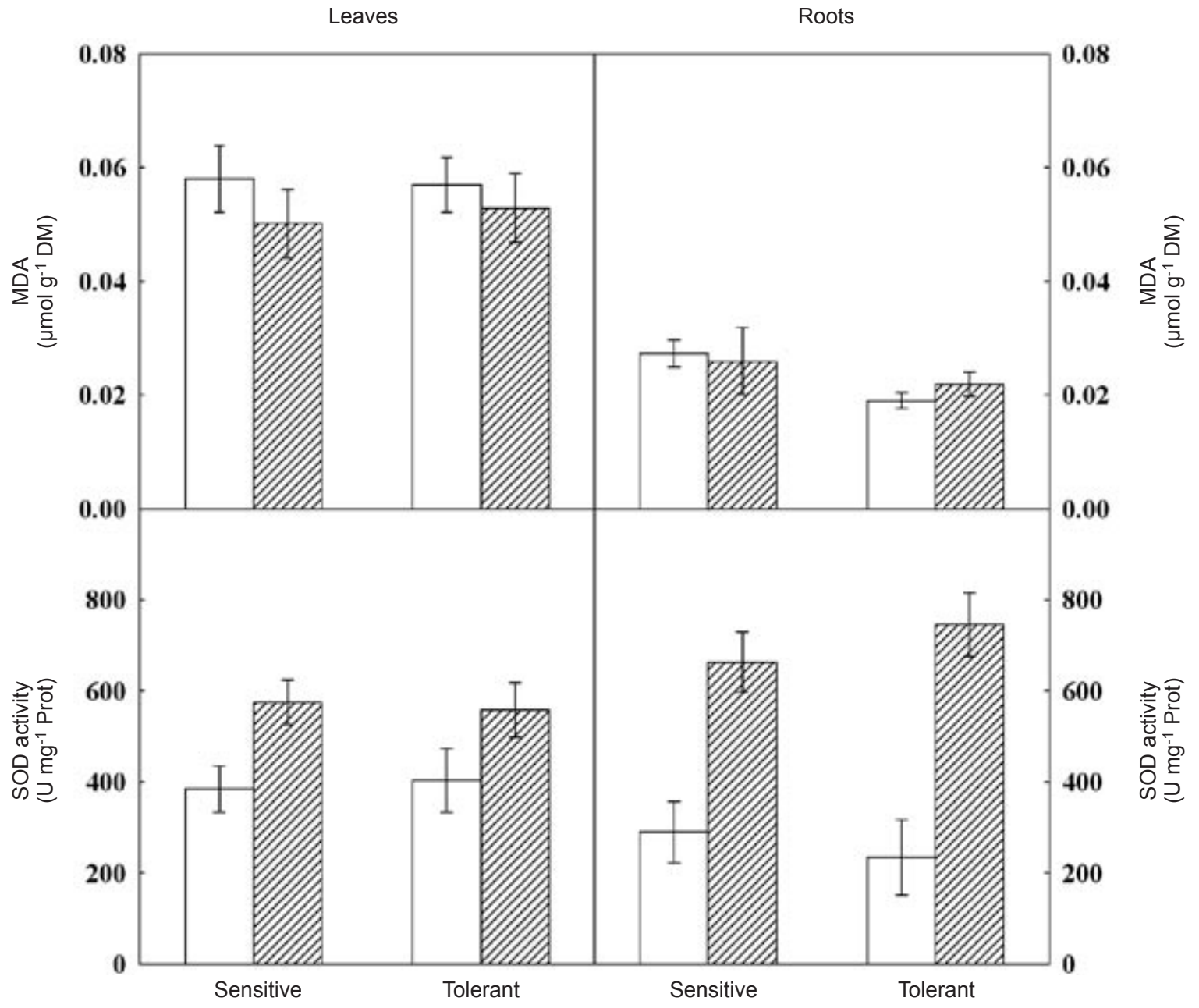

Figure 2. Lipid peroxidation, expressed by the content of malondialdehyde (MDA), and superoxide dismutase (SOD) activity in leaves and roots of two sorghum genotypes, differing in salt-tolerance. Plants were grown under control ( $\square$ ) and saline $(\square)$ conditions; values represent the mean and the bars indicate standard deviation. 
In addition to CAT, the activities of peroxidases (that also decompose $\mathrm{H}_{2} \mathrm{O}_{2}$ ) were studied. Leaf-APX activity (figure 3) decreased $48.9 \%$ and increased 476.1 $\%$ as a result of salt stress, in salt-sensitive and salt-tolerant genotypes, respectively. Root-APX activity in plants of the salt-sensitive genotype was not affected by salt stress, but there was an increase of $18.9 \%$ when plants from the salt-tolerant genotype were salt-stressed. With regard to leaf-GPX activity (figure 4), salt stress induced a reduction of $44.8 \%$ and an increase of $58.6 \%$ for salt-sensitive and salt-tolerant genotypes, respectively. Root-GPX activity was reduced $50.6 \%$ as a result of salt stress in the salt-sensitive genotype, but it was not affected by the same stress in the salt-tolerant one.
The antioxidant enzyme activity values were higher in roots than in leaves (figures 3 and 4), except for leaf-GR activity that was always higher than in the roots for both control and saline treatments, as well as for salt-sensitive and salt-tolerant genotypes (figure 4). Both leaf and rootGR activities were not affected by the salinity treatment in both genotypes. SOD activities in the control treatment were slightly higher in leaves than in roots, while in the saline treatment they were slightly higher in roots for both sensitive and tolerant genotypes (figure 2).

The relationship between the $\mathrm{H}_{2} \mathrm{O}_{2}$-producing activity and the total $\mathrm{H}_{2} \mathrm{O}_{2}$-scavenging activities [SOD/ $(\mathrm{CAT}+\mathrm{APX}+\mathrm{GPX})$ activity ratio] is shown in figure 5 . While there was a $209.7 \%$ increase in this ratio in leaves of the

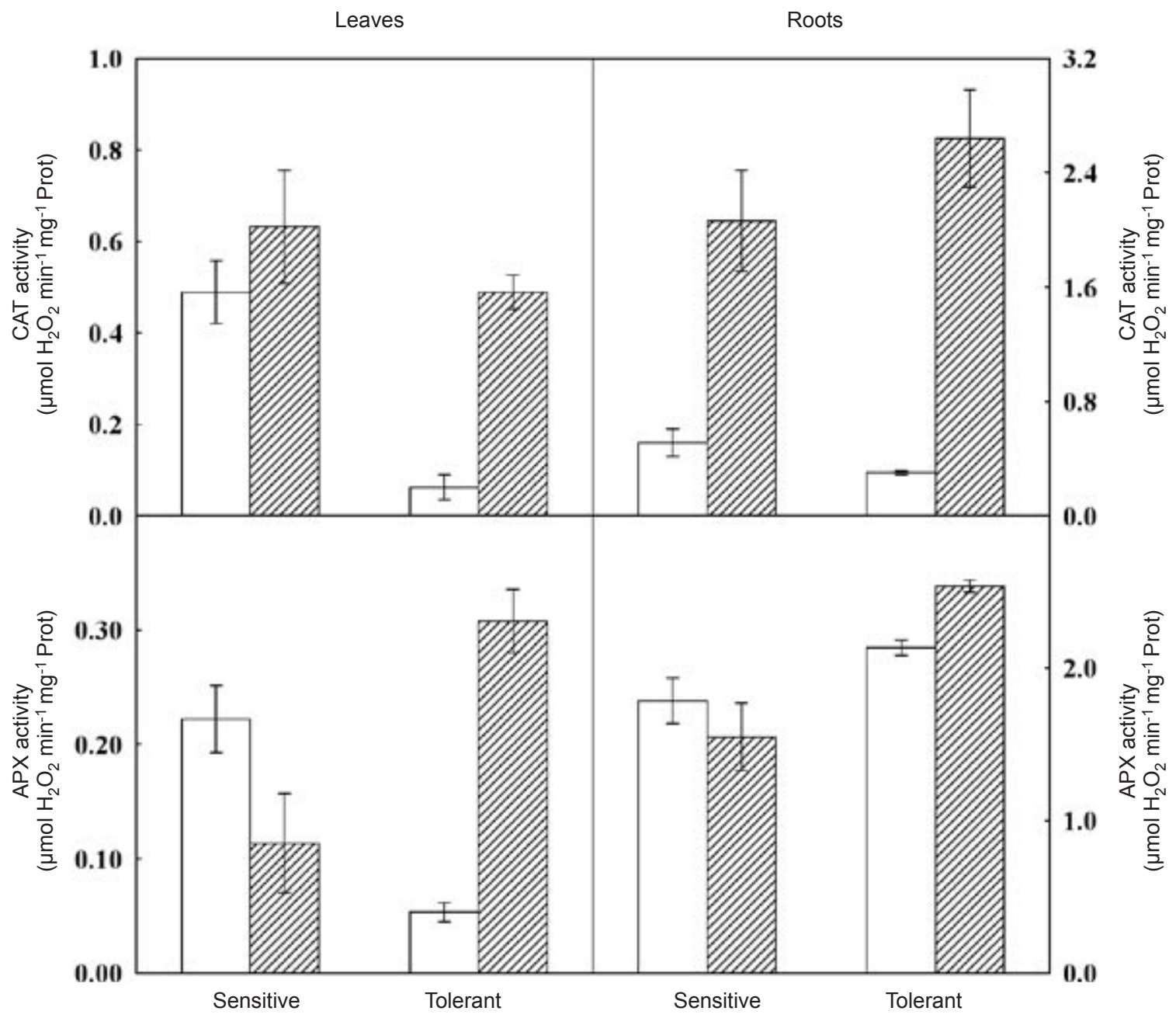

Figure 3. Catalase (CAT) and ascorbate peroxidase (APX) activity in leaves and roots of two sorghum genotypes, differing in salt-tolerance. Plants were grown under control $(\square)$ and saline $(\square)$ conditions; values represent the mean and the bars indicate standard deviation. 


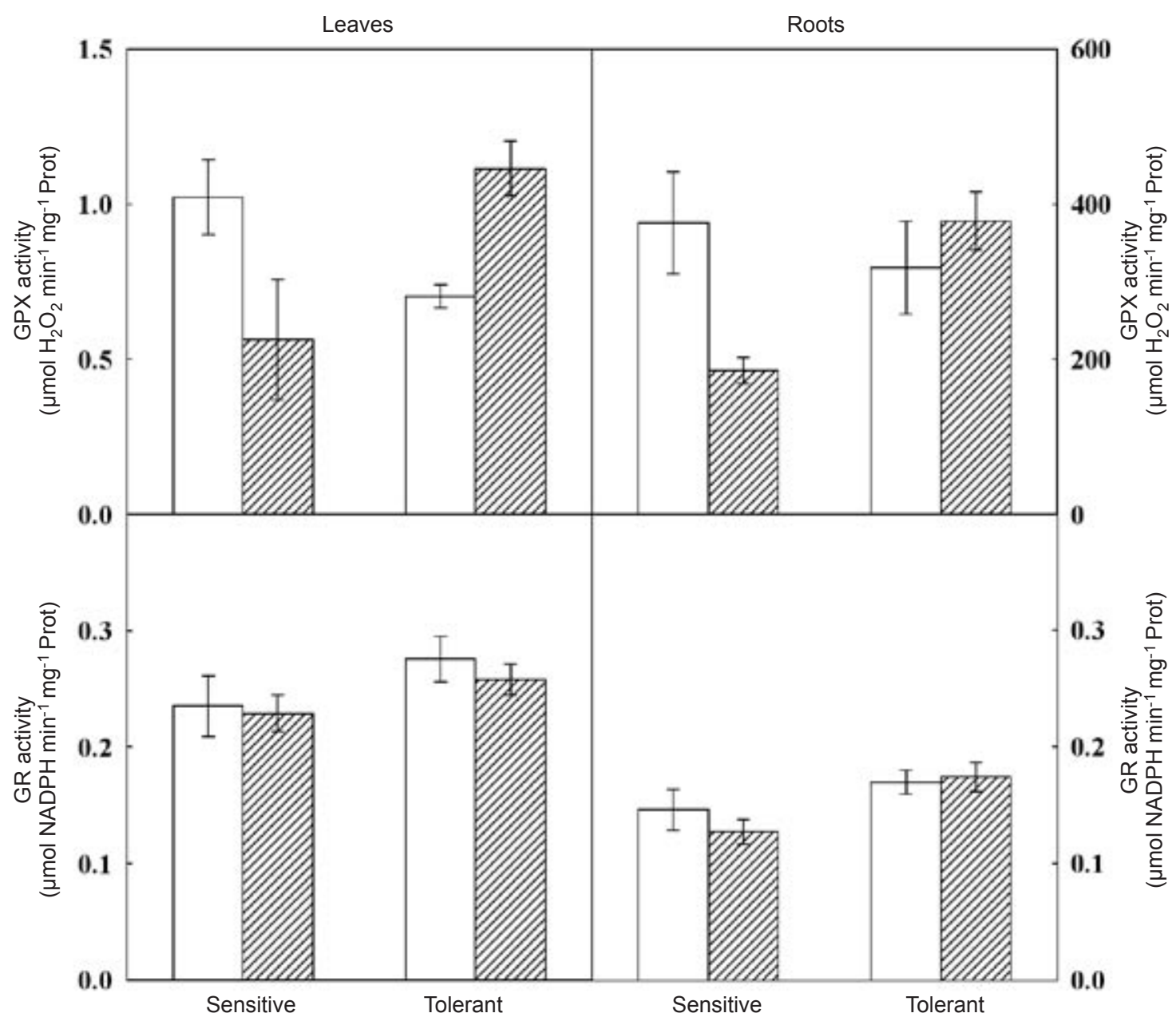

Figure 4. Guaiacol peroxidase (GPX) and glutathione reductase (GR) activity in leaves and roots of two sorghum genotypes, differing in salt-tolerance. Plants were grown under control $(\square)$ and saline $(\square)$ conditions; values represent the mean and the bars indicate standard deviation.

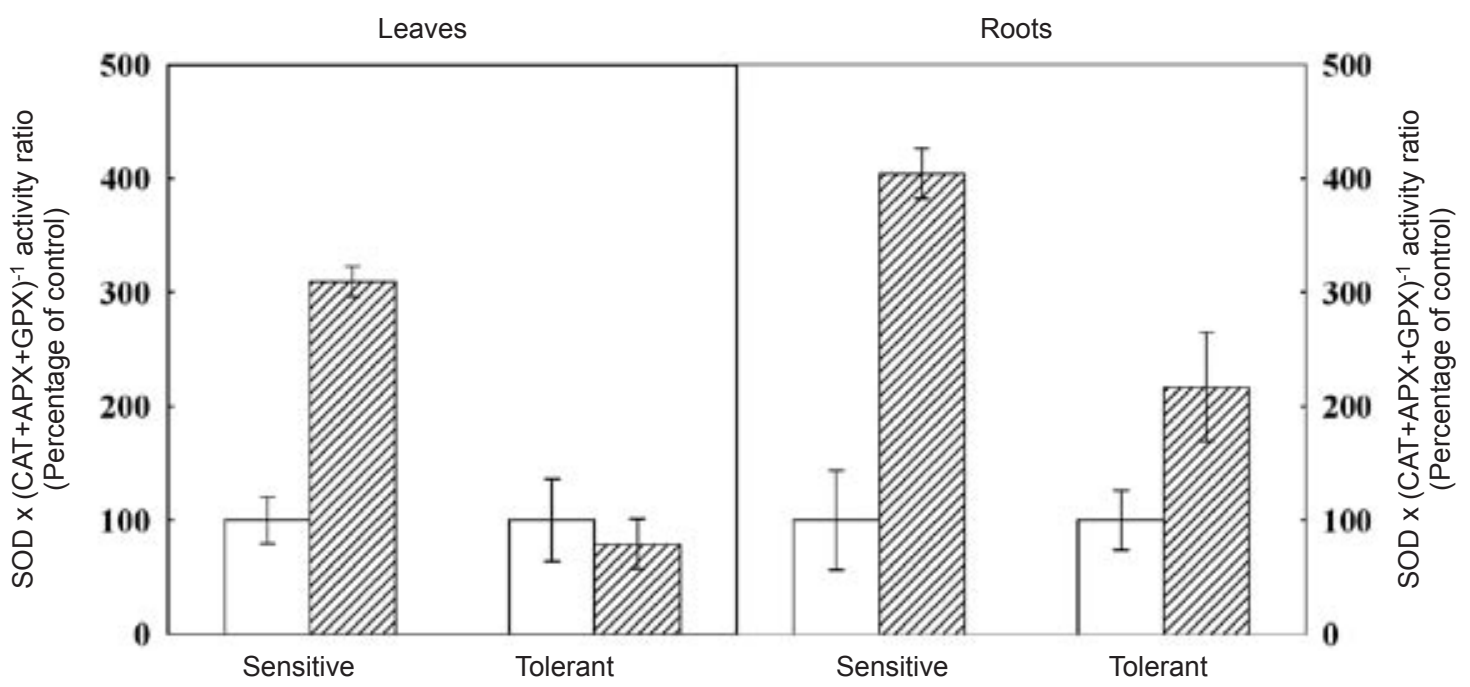

Figure 5. Relationship between the activity of $\mathrm{H}_{2} \mathrm{O}_{2}$ producing enzyme and that of the $\mathrm{H}_{2} \mathrm{O}_{2}$ scavenging enzymes [SOD $x$ $\left.(\mathrm{CAT}+\mathrm{APX}+\mathrm{GPX})^{-1}\right]$ activity ratio in leaves and roots of two sorghum genotypes, differing in salt-tolerance. Plants were grown under control $(\square)$ and saline $(\square)$ conditions; values represent the mean and the bars indicate standard deviation. 
salt-sensitive genotype as a result of salt stress, this leaf activity ratio was not affected by the stress in plants from the salt-tolerant genotype. In the roots, both genotypes showed increases in the $\mathrm{SOD} /(\mathrm{CAT}+\mathrm{APX}+\mathrm{GPX})$ activity ratio as a result of salt stress. However, this increase was much higher in the salt-sensitive (304.4\%) than in the salt-tolerant (116.7 $\%$ genotype.

\section{DISCUSSION}

It has been demonstrated that salinity induces oxidative stress in plant tissues, and lipid peroxidation has frequently been used as an indicator of oxidative stress when plants are subjected to salinity. This has been shown for Morus alba (Sudhakar et al., 2001), Lycopersicon esculentum (Mittova et al., 2002), Beta vulgaris (Bor et al., 2003), Oryza sativa (Vaidyanathan et al., 2003), and Gossypium hirsutum (Meloni et al., 2003). Our data are in disagreement with this idea mainly because we found no difference in either leaf or root lipid peroxidation between the control and saline treatments in plants of both salt-tolerant and salt-sensitive forage sorghum genotypes (figure 2). Similar results were obtained when sorghum plants were subjected to water stress (Zhang and Kirham, 1996), suggesting that lipid peroxidation cannot be regarded as the universal marker for water or salt tolerance in all plant species. However, lipid peroxidation is not the only oxidative stress damage, because reactive oxygen species (ROS) may also damage macromolecules such as DNA and proteins (Alscher et al., 1997; Pastori and Foyer, 2002). Therefore, one cannot exclude the possibility of oxidative damage involving other biomolecules, such as chlorophyll. The decrease in chlorophyll content of sorghum leaves as a result of salinity, especially in the salt-sensitive genotype (Lacerda et al., 2003) could be a result of oxidative damage.

To overcome the effects of salinity-induced oxidative stress, plants make use of a complex antioxidant system. Relatively higher activities of ROS-scavenging enzymes have been reported in tolerant genotypes when compared to susceptible ones, suggesting that the antioxidant system plays an important role in plant tolerance against environmental stresses. In the present study, a significant increase in leaf- and root-SOD activity was observed in both sorghum genotypes under saline conditions (figure 2), suggesting that SOD may function as a ROS scavenger, by converting $\mathrm{O}_{2}{ }^{--}$to $\mathrm{H}_{2} \mathrm{O}_{2}$ (Alscher et al., 2002). Recent studies have demonstrated that overexpression of mitochondrial Mn-SOD in transgenic Arabidopsis thaliana (Wang et al., 2004) and chloroplastic $\mathrm{Cu} / \mathrm{Zn}$-SOD in transgenic Nicotiana tabacum (Badawi et al., 2004a) can provide enhanced tolerance to salt stress. Similar results have been found in Morus alba (Sudhakar et al., 2001), Triticum aestivum (Sairam et al., 2002), and Lycopersicon sp (Mittova et al., 2002).

Even though a high SOD activity protects the plant against the superoxide radical, it cannot be considered solely responsible for membrane protection against peroxidation because it converts $\mathrm{O}_{2}{ }^{-}$to $\mathrm{H}_{2} \mathrm{O}_{2}$, which is also a ROS. This ROS should be then scavenged by other enzymes, such as catalase and peroxidases. The fact that leaf CAT activity of the salt-sensitive genotype in the control treatment was higher than in the tolerant genotype (figure 3 ) could be the result of genetic differences. However, when the plants were subjected to salt stress the increases in CAT activity were higher in the tolerant than in the sensitive genotype. Our results do show that leaf- and root-CAT activities increase with salt stress, and that this increase is more conspicuous in the salt-tolerant than in the salt-sensitive genotype (figure 3). Similar results have been observed when Beta maritime (halophyte) and the non-halophyte Beta vulgaris were studied (Bor et al., 2003), and when comparisons were made between genotypes of rice (Sudhakar et al., 2001) and wheat (Sairam et al., 2002), differing in salt tolerance. In addition to CAT, the activities of the peroxidases APX (figure 3) and GPX (figure 4) from both sorghum genotypes were also affected by salt stress. Salt stress either decreased (leaf-APX, leaf- and root-GPX) or did not affect (root-APX) the activities of these peroxidases in the salt-sensitive genotype, but in the salt-tolerant one there were increases in the activities of both leaf- and root-APX and of leaf-GPX, suggesting a strong correlation between salt tolerance and peroxidase activities. The same correlation was found for other plant species (Mittova et al., 2002; Harinasut et al., 2003), and the overexpression of cytosolic APX in tobacco chloroplasts enhanced the tolerance to salt stress, as determined by net photosynthesis (Badawi et al., 2004b). However, others have not found the same correlation between increase in peroxidase activity and salt tolerance (Siegel et al., 1982; Dionisio-Sese and Tobita, 1998). It is note worth that the contribution of GPX for the total $\mathrm{H}_{2} \mathrm{O}_{2}$ scavenging activity was about $43.1 \%$ in the leaves and 98.1 $\%$ in the roots for the salt-sensitive genotype, while for the salt-tolerant genotype it was 58.3 and $98.7 \%$ in leaves and roots, respectively.

Since APX and GR are key enzymes of the ascorbateglutathione cycle (Noctor and Foyer, 1998), this pathway could be a potential mechanism for sorghum acclimation or 
adaptation to salt stress. Even though in some species salt tolerance was associated with increases in both APX and GR activities (Bor et al., 2003; Harinasut et al., 2003), the same was not observed here. The increases observed in APX activity for the salt-tolerant genotype (figure 3 ) were not followed by GR activity (figure 4). These discrepancies could be related to the complexity of this cycle, that have enzymes coded by multigenic families whose products are localized in different cell compartments, and are regulated differently by stress conditions. For instance, in the cytosolic fraction of sorghum leaves subjected to water stress there was a decrease in monodehydroascorbate reductase (MDHAR) activity, and increased dehydroascorbate reductase (DHAR) activity (Zhang and Kirkham, 1996). In chloroplasts isolated from Lycopersicon pennellii plants and subjected to salt stress, MDHAR activity increased, GR remained unchanged, and that of DHAR was reduced (Mittova et al., 2002). In addition, the unchanged value in total enzyme activity may be masked by the differential contribution of the different isoforms present. Therefore, the relative importance of each enzyme of this cycle to salt tolerance still remains to be evaluated. The discrepancies in the data related in this paper could be also due to the fact that salt stress tolerance, besides being multigenic, is dependent upon plant species, stress intensity and duration, and interactions with several environmental factors (Flowers, 2004; Ashraf and Harris, 2004).

Although SOD is not the only $\mathrm{H}_{2} \mathrm{O}_{2}$-producing enzyme in plant tissues, the balance between the activity of this enzyme and that of the $\mathrm{H}_{2} \mathrm{O}_{2}$-scavenging enzymes in cells has been considered to be crucial in determining the levels of $\mathrm{O}_{2}{ }^{--}$and $\mathrm{H}_{2} \mathrm{O}_{2}$ (Badawi et al., 2004a). It was observed that $\mathrm{SOD} /(\mathrm{CAT}+\mathrm{APX}+\mathrm{GPX})$ leaf-activity ratio of the salt-sensitive genotype increased with salt stress, but when the salt-tolerant genotype was subjected to salt stress this ratio did not change (figure 5). The $\mathrm{SOD} /(\mathrm{CAT}+\mathrm{APX}+\mathrm{GPX}$ ) root-activity ratio increased in both genotypes in response to salt stress, however the highest increase was observed in the salt-sensitive genotype (figure 5). These results showed a strong correlation between salt tolerance and the antioxidant-enzymatic system, suggesting that the balance between the activity of $\mathrm{H}_{2} \mathrm{O}_{2}$-producing enzymes and that of the $\mathrm{H}_{2} \mathrm{O}_{2}$-scavenging enzymes plays an important role in providing a plant defense mechanism against salt-induced oxidative damage. Therefore, the induction of this antioxidative defense mechanism could be assumed to reflect a plant response required to overcome oxidative threats imposed by the environmental constraints. In fact, the $\mathrm{H}_{2} \mathrm{O}_{2}$ pre-treatment under growth conditions induced the antioxidant enzyme activities and enhanced salt tolerance in rice (Uchida et al., 2002) and maize (Azevedo Neto et al., 2005b). The fact that the salttolerant genotype (CSF20) accumulates less $\mathrm{Na}^{+}$and $\mathrm{Cl}^{-}$ in the leaves and maintains high levels of $\mathrm{K}^{+}$under salinity conditions, thus maintaining a suitable $\mathrm{Na}^{+} / \mathrm{K}^{+}$ratio (Lacerda et al., 2003) could well be related to the greater protection against the formation of ROS presented by this genotype. This protection would help maintain membrane integrity, and consequently account for the maintenance of $\mathrm{K}^{+}$-uptake and $\mathrm{Na}^{+}$-exclusion systems of the leaves.

In conclusion, the tolerance of the CSF20 genotype to salinity seems to be related to the efficiency of the antioxidant-enzymatic system against ROS accumulation, which would maintain the redox homeostasis and integrity of cellular components. Even though GPX has been attributed a major role as antioxidant enzyme in sorghum plants, it is the coordinated action of the several antioxidant enzymes that appears to play a key role in salt tolerance in this species. Although the results represent the situation at the end of the experimental period, and no data is available along plant development, they support the hypothesis that the higher efficiency of the antioxidant-enzymatic system of the CSF20 genotype could be considered as one of the factors responsible for its tolerance to salt stress. They also suggest that the ratio between SOD and $\mathrm{H}_{2} \mathrm{O}_{2}$-scavenging enzyme activities might be useful as a biochemical marker for salt tolerance in sorghum.

Acknowledgments: We thank Dr. Ladaslav Sodek for reviewing the English text, and acknowledge the financial support given by Conselho Nacional de Desenvolvimento Científico e Tecnológico (CNPq) and Coordenacão de Aperfeiçoamento de Pessoal de Nível Superior (CAPES).

\section{REFERENCES}

Alscher RG, Donahue JL, Cramer CL (1997) Reactive oxygen species and antioxidants: relationship in green cells. Physiol. Plant. 100:224-233.

Alscher RG, Erturk N, Heath LS (2002) Role of superoxide dismutases (SODs) in controlling oxidative stress in plants. J. Exp. Bot. 53:1331-1341.

Apel K, Hirt H (2004) Reactive oxygen species: metabolism, oxidative stress, and signal transduction. Annu. Rev. Plant Biol. 55:373-399.

Asada K (1992) Ascorbate peroxidase - a hydrogen peroxidescavenging enzyme in plants. Physiol. Plant. 85:235-241.

Ashraf M, Harris PJC (2004) Potential biochemical indicators of salinity tolerance in plants. Plant Sci. 166:3-16. 
Azevedo Neto AD, Prisco JT, Enéas-Filho J, Abreu CEB, Gomes-Filho E (2005a) Effect of salt stress on antioxidative enzymes and lipid peroxidation in leaves and roots of salttolerant and salt-sensitive maize genotypes. Environ. Exp. Bot. in press. doi:10.1016/j.envexpbot.2005.01.008.

Azevedo Neto AD, Prisco, JT, Enéas-Filho J, Medeiros, JR, Gomes-Filho, E (2005b) Hydrogen peroxide pre-treatment induces salt-stress acclimation in maize plants. J. Plant. Physiol. 162:1114-1122.

Badawi GH, Yamauchi Y, Shimada E, Sasaki R, Kawano N, Tanaka K, Tanaka K (2004a) Enhanced tolerance to salt stress and water deficit by overexpressing superoxide dismutase in tobacco (Nicotiana tabacum) chloroplasts. Plant Sci. 166:919-928.

Badawi GH, Kawano N, Yamauchi Y, Shimada E, Sasaki R, Kubo A, Tanaka K (2004b) Over-expression of ascorbate peroxidase in tobacco chloroplasts enhances the tolerance to salt stress and water deficit. Physiol. Plant. 121:231-238.

Beers Jr RF, Sizer IW (1952) A spectrophotometric method for measuring the breakdown of hydrogen peroxide by catalase. J. Biol. Chem. 195:133-140.

Bernstein N, Silk WK, Läuchli A (1995) Growth and development of sorghum leaves under conditions of $\mathrm{NaCl}$ stress: possible role of some mineral elements in growth inhibition. Planta 196:699-705.

Bor M, Özdemir F, Türkan I (2003) The effect of salt stress on lipid peroxidation and antioxidants in leaves of sugar beet Beta vulgaris L. and wild beet Beta maritima L. Plant Sci. 164:77-74.

Bradford MM (1976) A rapid and sensitive method for the quantification of microgram quantities of protein utilizing the principle of protein-dye binding. Anal. Biochem. 72:246-254.

Clark RB (1975) Characterization of phosphatase of intact maize roots. J. Agric. Food. Chem. 23:458-460.

Dionisio-Sese ML, Tobita S (1998) Antioxidant responses of rice seedlings to salinity stress. Plant Sci. 135:1-9.

Flowers TJ (2004) Improving crop salt tolerance. J. Exp. Bot. 55:307-319.

Foyer CH, Halliwell B (1976) The presence of glutathione and glutathione reductase in chloroplasts: a proposed role in ascorbic acid metabolism. Planta 133:21-25.

Giannopolitis CN, Ries SK (1977) Superoxide dismutases. I. Occurrence in higher plants. Plant Physiol. 59:309-314.

Gosset DR, Millhollon EP, Lucas MC (1994) Antioxidant response to $\mathrm{NaCl}$ stress in salt-tolerant and salt-sensitive cultivars of cotton. Crop Sci. 34:706-714.

Harinasut P, Poonsopa D, Roengmongkol K, Charoensataporn R (2003) Salinity effects on antioxidant enzymes in mulberry cultivar. ScienceAsia 29:109-113.

Heath RL, Packer L (1968) Photoperoxidation in isolated chloroplasts. I. Kinetics and stochiometry of fatty acid peroxidation. Arch. Biochem. Biophys. 125:189-198.

Lacerda CF, Cambraia J, Oliva MA, Ruiz HA (2001) Plant growth and solute accumulation and distribution in two sorghum genotypes, under $\mathrm{NaCl}$ stress. Rev. Bras. Fisiol. Veg. 13:270-284.

Lacerda CF, Cambraia J, Oliva MA, Ruiz HA(2005) Changes in growth and solute concentrations in sorghum leaves and roots during salt stress recovery. Environ. Exp. Bot. 54:69-76.
Lacerda CF, Cambraia J, Oliva MA, Ruiz HA, Prisco JT (2003) Solute accumulation and distribution during shoot and leaf development in two sorghum genotypes under salt stress. Environ. Exp. Bot. 49:107-120.

McKersie BD, Leshem YY (1994) Stress and stress coping in cultivated plants. Kluwer Academic Publishes, London.

Meloni DA, Oliva MA, Martinez CA, Cambraia J (2003) Photosynthesis and activity of superoxide dismutase, peroxidase and glutathione reductase in cotton under salt stress. Environ. Exp. Bot. 49:69-76.

Mittova V, Tal M, Volokita M, Guy M (2002) Salt stress induces up-regulation of an efficient chloroplast antioxidant system in the salt-tolerant wild tomato species Lycopersicon pennellii but not in the cultivated species. Physiol. Plant. 115:393-400.

Nakano Y, Asada K (1981) Hydrogen peroxide is scavenged by ascorbate-specific peroxidases in spinach chloroplasts. Plant Cell Physiol. 22:867-880.

Noctor G, Foyer CH (1998) Ascorbate and glutathione: keeping active oxygen under control. Annu. Rev. Plant Physiol. Plant Mol. Biol. 49:249-279.

Pastori GM, Foyer CH (2002) Common components, networks, and pathways of cross-tolerance to stress. The central role of 'redox' and abscisic acid-mediated controls. Plant Physiol. 129:7460-7468.

Plewa MJ, Smith SR, Wagner ED (1991) Diethyldithiocarbamate suppresses the plant activation of aromatic amines into mutagens by inhibiting tobacco cell peroxidase. Mutation Res. 247:57-64.

Sairam RK, Rao KV, Srivastava GC (2002) Differential response of wheat genotypes to long-term salinity stress in relation to oxidative stress, antioxidant activity and osmolyte concentration. Plant Sci. 163:1037-1046.

Shigeoka S, Ishikawa T, Tamoi M, Miyagawa Y, Takeda T, Yabuta Y, Yoshimura Y (2002) Regulation and function of ascorbate peroxidase isoenzymes. J. Exp. Bot. 53:1305-1319.

Siegel SM, Chen J, Kottenmeier W, Clark K, Siegel BZ, Chang H (1982) Reduction in peroxidase in Cucumis, Brassica and other seedlings cultured in saline waters. Phytochemistry 21:539-542.

Sudhakar C, Lakshmi A, Giridarakumar S (2001) Changes in the antioxidant enzyme efficacy in two high yielding genotypes of mulberry (Morus alba L.) under NaCl salinity. Plant Sci. 161:613-619.

Uchida A, Jagendorf AT, Hibino T, Takabe T, Takabe T (2002) Effects of hydrogen peroxide and nitric oxide on both salt and heat stress tolerance in rice. Plant Sci. 163:515-523.

Urbanek H, Kuzniak-Gebarowska E, Herka K (1991) Elicitation of defense responses in bean leaves by Botrytis cinerea polygalacturonase. Acta Phys. Plant. 13:43-50.

Vaidyanathan H, Sivakumar P, Chakrabarty R, Thomas G (2003) Scavenging of reactive oxygen species in $\mathrm{NaCl}$-stressed rice (Oryza sativa L.) - differential response in salt-tolerant and sensitive varieties. Plant Sci. 165:1411-1418.

Wang Y, Ying Y, Chen J, Wang X (2004) Transgenic Arabidopsis overexpressing Mn-SOD enhanced salt-tolerance. Plant Sci. 167:671-677.

Zhang J, Kirkham MB (1996) Enzymatic responses of the ascorbate-glutathione cycle to drought in sorghum and sunflower plants. Plant Sci. 113:139-147. 